\title{
STUDI RETORSPEKTIF HUBUNGAN ANTARA VARIETAS KONSUMSI BUAH DENGAN STATUS GLIKEMIK PADA PENDERITA DIABETESS MELITUS TIPE 2
}

\author{
Juli Widiyanto, Isnaniar, Trisiwi Kusuma Ningrum \\ Universitas Muhammadiyah Riau \\ Jl. Tuanku Tambusai Ujung, Pekanbaru 28291, Riau \\ e-mail: juliwidiyanto@umri.ac.id
}

\begin{abstract}
ABSTRAK
Latar Belakang: Penyakit infeksi tidak menular dewasa ini menjadi ancaman tersendiri dalam kehidupan masyarakat, diabetes mellitus adalah salah satunya, Pertumbuhan diabetes melitus di Indonesia sebesar 15,2\% atau dari 8.426.000 orang pada tahun 2.000 dan diperkirakan menjadi 21.257.000 orang di tahun 2030. Penelitian metaanalisis oleh Miller dkk, 5 menemukan pasien diabetes yang mengkonsumsi diet indeks glikemik rendah mengalami penurunan kadar HbA1c 0,43\% (CI 0,72-0,13) dan penurunan kadar protein terglikosilasi 7,4\%. Penelitian metaanalisis menunjukkan diet dengan tinggi serat mempengaruhi kadar glukosa darah. Didapatkan penurunan kadar glukosa post prandial $+21 \%$. Penelitian Andrew et.al (2012) membuktikan bahwa konsumsi buah dan sayuran yang bervariasi dapat mengurangi factor risiko kejadian diabetes tipe2

Tujuan: penelitian ini bertujuan untuk menganalisis hubungan antara varietas konsumsi buah dengan status glikemik pada penderita diabetes melitus tipeII di Wilayah Kerja Puskesmas Sidomulyo dan Puskesmas Harapan Raya Pekanbaru.

Metode Peneliian: Penelitian ini merupakan penelitian analitik observasional dengan rancangan case control study. Teknik sampling yang digunakan adalah purposive sampling. Teknik analisis yang digunakan adalah dengan uji Person Chi Squer

Hasil penelitian: Hasil penelitian membuktikan bahwa terdapat berhubungan yang bermakna antara varietas konsumsi buah juga berhubungan dengan status glikemik, hal tersebut dibuktikan dengan nilai p-value $<0,05$ yaitu 0,017. Dengan OR: 3,6 dan CI95\%: 1,22 - 10,61. Sehingga dapat disimpulkan bahwa varietas konsumsi buah pada penderita diabetes mellitus tipe dua berhubungan erat dengan status glikemik pada penderita diabetes mellitus.

Kesimpulan: Simpulan penelitian ini adalah terdapat hubugan yang bermakna antara varietas konsumsi buah dengan status glikemik
\end{abstract}

Kata kunci: Diabetes Mellitus, Varietas Buah, Status Glikemik

\section{PENDAHULUAN}

Penyakit infeksi tidak menular dewasa ini menjadi ancaman tersendiri dalam kehidupan masyarakat, diabetes mellitus adalah salah satunya, Pertumbuhan diabetes melitus di Indonesia sebesar $15,2 \%$ atau dari 8.426 .000 orang pada tahun 2.000 dan diperkirakan menjadi 21.257.000 orang di tahun 2030 (Perkeni, 2011). Indonesia merupakan negara keempat yang memiliki jumlah penderita DM terbanyak di dunia. dimana hanya $50 \%$ yang menyadari mengidap DM dan diantaranya sekitar 30\% yang datang berobat secara teratur (ADA, 2006). Menurut laporan Riset Kesehatan Dasar (Riskesdas) tahun 2013, prevalensi DM di Indonesia sebesar $1,5 \%$. hasil penelitian yang dilakukan oleh DiabCare di Indonesia, diketahui bahwa 47,2\% memiliki kendali yang buruk pada glukosa darah plasma puasa $>130 \mathrm{mg} / \mathrm{dl}$ pada penderita DM tipe 2 (Soewando, 2011). Soewando dan Pramono tahun 2011 melanjutkan penelitian dari Riskesdas, dari $5,7 \%$ total penderita diabetes melitus di Indonesia, sekitar 4,1\% adalah kategori diabetes melitus tidak terdiagnosis dan 1,6\% adalah diabetes mellitus.

Beberapa penelitian epidemiologis membuktikan bahwa ada kecendrungan peningkatan angka insidensi danprevalensi diabetes mellitus tipe 2 diseluruh penjuru dunia (Cheng, 2005). WHO memprediksi adanya peningkatan jumlah penyandang diabetes yang tinggi pada tahun-tahun yang akan datang. WHO memprediksi kenaikan jumlah penderita diabetes tahun 2030 mencapai 21,3 juta jiwa, hal ini juga senanda dengan internasional diabetes federation (IDF) pada tahun 2009 memprediksi kenaikan jumlah penyandang diabetes 7,0 juta dan 
memperkirakan tahun 2030 mencapai 12,0 juta. Walaupun ada perbedaan angka prevalensi diabetes mellitus, namun keduanya menunjukan angka peningkatan 2-3 kali lipat pada tahun 2030 ( Shaw \& Zimmet, 2010).

Berbagai bukti menunjukan bahwa komplikasi diabetes dapat dicegah dengan control glikemik yang optimal, karena dengan control glikemik dapat terpantau perkembangan penyakit diabetes, namun demikian di indosesia control glikemik belum dapat diupayakan secara maksimal, mengingat berbagai latarbelakang permasalahan penduduk yang sangat heterogen dan masih rendahnya kesadaran untuk hidup sehat secara optimal ( Artati \& Rosdiana, 2015).

Secara laboratoris, pengendalian metabolik dapat dinilai dari hasil pemantauan rutin glukosa darah sewaktu di rumah, HbA1C, dan fruktosamin. Fruktosamin merupakan hasil reaksi non-enzimatik Maillard antara residu glukosa dan asam amino (Natah dkk, 1997). Pemeriksaan fruktosamin dapat digunakan sebagai alternatif pengganti pemeriksaan HbAlc untuk pengendalian indeks glikemik karena secara teknik lebih mudah dan murah serta waktu pengendalian glikemik lebih pendek dibanding HbAlc (2-4 minggu dibandingkan 612 minggu) (Petiti \& Dudl, 2001).

Beberapa penelitian tentang diet indeks glikemik rendah menunjukkan hasil kontroversial. Dilaporkan terdapat penelitian yang menunjukkan perbaikan pengendalian glikemik secara bermakna namun beberapa penelitian menunjukkan tidak ada perbedaan. Penelitian metaanalisis (Alison, dkk, 2014), menemukan pasien diabetes yang mengkonsumsi diet indeks glikemik rendah mengalami penurunan kadar $\mathrm{HbA} 1 \mathrm{c} 0,43 \%$ (CI 0,72-0,13) dan penurunan kadar protein terglikosilasi 7,4\%. Penelitian metaanalisis menunjukkan diet dengan tinggi serat mempengaruhi kadar glukosa darah. Didapatkan penurunan kadar glukosa post prandial $+21 \%$ (Anderson \& Kendall, 2004).

Di Indonesia dari hasil riset kesehatan dasar 2013 angka penderita DM yang terdiagnosis berjumlah 41.071 jiwa dan dengan gejala 8.214 jiwa, dan data dinas Kesehatan Riau tahun 2013 jumlah penderita diabetes melitus terbanyak pada kelompok umur 45-54 tahun (251 kasus), kedua kelompok umur 60-69 (130 kasus) dan ketiga kelompok Umur 25-44 tahun (126 kasus). Sementara itu, data Profil Kesehatan Riau tahun 2013 menyatakan bahwa di Pekanbaru jumlah penderita diabetes melitus berjumah 507 kasus dan penelitian Riani di puskesmas sidomulyo kecamatan Tampan kota Pekanbaru menunjukkan hasil dari 120 subjek yang diteliti $29,17 \%$ merupakan diabetes melitus tidak terdiagnosis. Perubahan status glikemik pada penderita diabetes dipengaruhi oleh banyak factor salah satunya adalah pola konsumsi makanan terutama buah-buahan sehingga perpengaruh pada status glikemik, sehingga kuantitas dan varietas buah yang dikonsumsi penderita sangat menentukan status glikemik tersebut (Yusra, 2011). Penelitian membuktikan bahwa konsumsi buah dan sayuran yang bervariasi dapat mengurangi factor risiko kejadian diabetes tipe2 (Andrew, 2012).

\section{METODOLOGI PENELITIAN}

Penelitian ini merupakan penelitian analitik observasional. Desain penelitian yang digunakan adalah Case Control Study (Armenian, 2009), yaitu suatu rancangan yang merupakan rancangan penelitian yang pengukuran atau pengamatannya di lakukan dengan cara menentukan kasus dan control kemudian mengkroscek kebelakang variable perlakuan secara bertahap. Penelitian melakukan pengukuran atau pengamatan tentang Hubungan Antara kuantitas dan varietas konsumsi buah dengan status glikemia pada penderita diabetes mellitus tipe 2 .

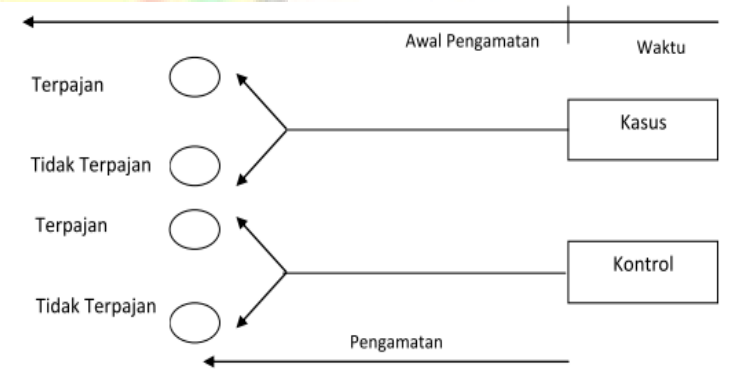

Gambar 1 Skema Diagram Case Control Study (Retrospektif) 
Variabel yang diukur atau diamati pada penelitian ini adalah kuantitas konsumsi buah yang dikonsumsi penderita DM yang dikategorikan (cukup dan tidak cukup), varietas konsumsi buah yang dikategorikan (bervariasi dan tidak bervariasi) dan variable status glikemik penderita DM yang di ukur kadar glukosa darahnya (hiperglikemia atau tidak).

Analisis data pada penelitian ini dilakukan menggunakan alat bantu komputer dengan program SPSS for windows release 17.0 dengan tahapan analisis sebagai berikut: Analisis univariat dilakukan dengan cara membuat distribusi frekuensi dari setiap variabel, hasil analisis ini disajikan dalam bentuk table dan narasi yang meliputi: Karakteristik Penderita diabetes, Kuantitas konsumsi buah pada Penderita diabetes, Varietas konsumsi buah pada penderita diabetes, Status glikemik penderita diabetes. Dan Analisis bivariat dilakukan untuk menguji hubungan antara dua variabel yaitu masing-masing variabel bebas dengan variabel terikat. Uji statistik yang akan digunakan adalah uji chi square dengan menghitung signifikansi. Tingkat kepercayaan ditentukan $\mathrm{p}=0,05$ dengan confident interval 95\%: Jika nilai $p>0,05$ maka hipotesis penelitian ditolak. Jika nilai $\mathrm{p}<0,05$ maka hipotesis penelitian diterima. Selanjutnya juga diperoleh nilai besar risiko (Odds Ratio/OR) paparan terhadap kasus dengan menggunakan table $2 \times 2$ sebagai berikut:

\section{Tabel 1}

\section{Tabel Kontingensi}

\begin{tabular}{lllll}
\hline \multirow{2}{*}{ No } & Kuantitas\& & \multicolumn{2}{l}{ Status Glikemik } & Total \\
\cline { 3 - 4 } & Varietas & Tinggi & Rendah & \\
\hline 1 & $(+)$ & $\mathrm{a}$ & $\mathrm{B}$ & $\mathrm{a}+\mathrm{b}$ \\
2 & $(-)$ & $\mathrm{c}$ & $\mathrm{D}$ & $\mathrm{c}+\mathrm{d}$ \\
\hline & Total & $\mathrm{a}+\mathrm{c}$ & $\mathrm{b}+\mathrm{d}$ & $\mathrm{a}+\mathrm{b}+\mathrm{c}+\mathrm{d}$ \\
\hline
\end{tabular}

\section{HASIL DAN PEMBAHASAN}

Berdasarkan hasil penelitian yang telah dilakukan di Puskesmas Harapan Raya dan Puskesmas Rawat Inap Sidomulyo, dapat tergambar pada table berikut:

\section{Analisis Univariat}

Tabel 1 Distribusi Frekuensi karakteistik Responden $(\mathrm{n}=66)$

\begin{tabular}{llll}
\hline No & Variabel & Frekuensi & Persentase \\
\hline 1 & Jenis & & \\
& Kelamin: & & \\
& Laki - Laki & 4 & 6,1 \\
& Perempuan & 62 & 93,9 \\
\hline 2 & TK & & \\
& Pendidikan: & & \\
& Rendah & 20 & 30,3 \\
& Tinggi & 46 & 69,7 \\
\hline 3 & Pekerjaan: & & \\
& PNS & 2 & 3,0 \\
& Swasta & 1 & 1,5 \\
& IRT & 48 & 72,7 \\
& Lain-lain & 15 & 22,7 \\
\hline 4 & Diagnosis: & & \\
& Diabetes & 33 & 50,0 \\
& Tidak & 33 & 50,0 \\
& Diabetes & & \\
\hline 5 & Usia: & & \\
& Berisiko & 39 & 59,1 \\
& Tidak & 27 & 40,9 \\
& Berisiko & & \\
\hline
\end{tabular}

Berdasarkan table daiatas, dapat disimpulkan bahwa jenis kelamin responden adalah berjenis kelamin perempuan yaitu $93,9 \%$, Pendidikan responden adalah Tingkat Pendidikan Tinggi yaitu $63,7 \%$, Pekerjaan Responden adalah IRT yaitu $72,7 \%$, Usia Responden rata-rata berisiko yaitu $59,1 \%$.

Berdasarkan karakteristik diatas, yang memiliki korelasi terhadap status glikemik adalah usia responden.

Diabetes Mellitus adalah suatu kelompok penyakit metabolik yang memiliki karakteristik hiperglikemia yang terjadi karena gangguan sekresi insulin, kerja insulin, atau keduaduanya, gangguan metabolic biasanya didukung oleh penurunan fungsi organ tubuh seseorang terutama fungsi pancreas (Rahayu \& Zakir, 2013). Hasil penelitian riskesdas usia $>15$ tahun yang terpapar lifestyle yang kurang sehat lebih dari 5 tahun berpotensi terhadap gangguan metabolic dan cardiovaskuler (Ike \& Okosun, 2015).

Diabetes Melitus dapat menyerang warga penduduk dari berbagai lapisan, baik dari segi ekonomi rendah, menengah, atas, ada pula dari segi usia. Tua maupun muda dapat menjadi penderita DM. Umumnya manusia mengalami 
perubahan fisiologi yang secara drastis menurun dengan cepat setelah usia 40 tahun. Diabetes sering muncul setelah seseorang memasuki usia rawan, terutama setelah usia 45 tahun pada mereka yang berat badannya berlebih, sehingga tubuhnya tidak peka lagi terhadap insulin. Teori yang ada mengatakan bahwa seseorang $\geq 45$ tahun memiliki peningkatan resiko terhadap terjadinya DM dan intoleransi glukosa yang di sebabkan oleh faktor degeneratif yaitu menurunya fungsi tubuh, khususnya kemampuan dari sel $\beta$ dalam memproduksi insulin (Egede \& Ellis, 2010).

Prevalensi kasus diabetes di dunia pada rentang usia 20 - 79 Tahun sebesar $6,4 \%$ dari 285 juta usia dewasa pada tahun 2010 dan meningkat $7,7 \%$ dari 439 juta pada tahun 2030. Dan antrara tahun 2010 - 2030 terjadi peningkatan sebesar $69 \%$ pada Negara maju dan $20 \%$ pada Negara berkembang (Shaw \& Zimmet, 2010).

Hasil penelitian ini juga sejalan dengan penelitian yang dilakukan sebelelumnya oleh Ayu dan Indirawati yang mengemukakan bahwa, prevalensi DM di Indonesia pada penduduk usia $>15$ tahun meningkat dari 1,52,3\% menjadi $5,6 \%$ pada tahun 1993 (Muthukumaran,dkk, 2013). Hasil studi epidemiologi tentang DM di Manado juga menunjukan angka yang lebih tinggi yaitu $6,1 \%$.sejalan dengan apa yang di kemukakan oleh Ayu dan Indirawati pada penelitiannya (Betteng \& Mayulu, 2014)

\section{Analisis Bivariat}

Tabel 2 Hubungan antara Varietas Konsumsi Buah dengan Status Glikemik

\begin{tabular}{lllll}
\hline Varietas & \multicolumn{2}{l}{ Status Glikemik } & P- & OR/CI95\% \\
\cline { 2 - 3 } & Tinggi & Normal & Value & \\
\hline Bervariasi & 10 & 32 & 0,017 & $3,66 /$ \\
Tidak & 12 & 12 & & $1,23-10,88$ \\
Bervariasi & & & & \\
\hline
\end{tabular}

Berdasarkan table diatas, dapat dilihat bahwa terdapat hubungan yang bermakna hubungan antara varietas konsumsi buah dengan status glikemik, hal tersebut dibuktikan dengan nilai pValue $<0,05$ yaitu 0,0017. dengan OR: 3,6 dan CI95\%: $1,23-10,88$.
Artinya bahwa pasien yang Penelitian tersebut memberikan gambaran bahwa Varietas dan kuantitas konsumsi buah berhubungan erat dengan status glikemik dan penderita yang kuantitasnya sedikit dalam mengkonsumsi buah berisiko 3,6 kali untuk terjadi peningkatan glukosanya jika dibandingkan dengan penderita yang mengkonsumsi buah dalam jumlah yang banyak.

Hal tersebut sesuai dengan hasil kritikal review yang menjelaskan bahwa konsumsi sayuran dan buah-buahan dapat meningkatkan pencegahan terhadap penyakit diabetes, stroke dan jantung koroner dan termasuk obesitas (Hainer dkk,2012)

Penelitian tersebut juga didukung dengan hasil penelitian mebuktikan bahwa pemberian jus buah naga merah dapat menurunkan kadar glukosa darah tikus putih jantan yang dibuat diabetik pada semua dosis sebanding dengan efek hipoglikemik dari glibenklamid (Muthukumaran,dkk, 2013). Penelitian di amerika membuktikan bahwa konsumsi makanan tinggi karbohidrat dan rendah fiber memiliki risiko terhadap peningkatan kasus diabetes mellitus tipe 2, sehingga kuantitas dan kualitas konsumsi tinggi karbohidrat dan rendah fiber merupakan factor sangat penting untuk dihindari untuk mencegah kejadian DM (Sluijs,dkk 2010) kandungan fiber yang terdapat dalam buah menjadi salah satu factor yang dapat menurunkan angka risiko diabetes mellitus, karena kandungan gulanya cenderung lebih sesuai dengan fisiologi tubuh manusia (Mokhdad, dkk, 2001)

Terapi nutrisi sangat direkomendasikan untuk mengatur dan mengendalikan penayakit diabetes mellitus pada orang dewasa terutama pada penderita yang memiliki riwayat diabetes mellitus (Alison dkk, 2012)

Tidak adanya hubungan antara menggunakan jamban sehat dengan kejadian diare pada bayi karena diare merupakan salah satu penyakit yang penyebabnya memiliki banyak faktor penyebab, yang berarti tidak hanya dapat disebabkan oleh penggunaan jamban tetapi juga dapat di sebabkan oleh pemberian ASI eklusif maupun perilaku 
dalam mencuci tangan menggunakan air bersih dan sabun.

\section{KESIMPULAN}

Berdasarkan hasil penelitian dapat disimpulkan bahwa terdapat hubungan yang bermakana anatara kuantitas dan varietas konsumsi buah dengan status glikemik pada penderita diabetes mellitus tipe 2, kuantitas konsumsi buah yang sedikit berisiko meningkatkan kadar gula darah 3,6 kali jika dibandingkan dengan yang mengkonsumsi buah banyak

\section{DAFTAR PUSTAKA}

ADA. (2006). Position Statement: Standard of Medical Care In Diabetes-2006. Diab Care. 29(1):S4-S42

Anderson JW RK, Kendall CW. (2004). Carbohydrate and fiber recommendations for individuals with diabetes: A quantitative assessment and meta-analysis of the evidence. Jurnal Am Col Nutr ;35:5-17.Soewando P PL. (2011). Prevalence, Characteristic, and Predictors of Pre-Diabetes in Indonesia: Department of Internal Medicine, Faculty of Medicine of University Indonesia

Andrew J.C (2012). Aprospective Study of the association between quantity and variety of fruit and vegetable intake and incident type 2 diabetes. Diabetes Care Journal (35).

Alison B. Evert JLB, (2014). Marjorie Cypress, Stephanie A. Dunbar, Marion J. Franz, Elizabeth J. Mayer-Davis,Joshua J. Neumiller, PharmD, Robin Nwankwo,Cassandra L. Verdi, Patti Urbanski, William S. Yancy Jr. Nutrition Therapy Recommendations for the Management of Adults With Diabetes. Jurnal Diabetes Care ;37(1).

Armenian HK. (2009). The Case-Control Method ; Design And Applications. Los Angles, California: Oxford University Press.

Artanti PM, H Rosdiana, D. (2015). Angka Kejadian Diabetes Melitus Tidak
Terdiagnosis pada Masyarakat Kota Pekanbaru. Jom FK (2).

Betteng R.D.P, dan Mayulu,N. (2014). Analisa Faktor Risiko Penyebab Terjadinya Diabetes Mellitus Tipe 2 Pada Wanita Usia Produktif di Puskesmas Wawonasa. Jurnal e-Biomedik (eBM);2(2).

Cheng D. (2005). Prevalence, Predisposition and Prevention of Type II. Diabetes. Nutrition \& Metabolism. 2 (29).

Egede L. dan Ellis C. (2010). Diabetus mellitus II and depression: Global perspectives; 87(3):302-12.

Heiner AB, Bub A.,Ellinger, S., Haller, D., Kroke, A., Bonnet, E.L., Mu"ller, M.J., Oberritter, H., Schulze, M., Stehle, P .,Watzl, B. (2012). Critical review: vegetables and fruit in the prevention of chronic diseases. Eur Jurnal Nutr ;51:637-63.

Ike S. Okosun RL. (2015). Prediabetes awareness, healthcare provider's advice, and lifestyle changes in American adults.International Journal of Diabetes Mellitus (3) 11-8.

Mokhdad A.H.E.S.F, Bowman,B.A., Dietz,W.H., Vinicord,F., Mark, J.S. (2003) Prevalence of obesity, Diabetes, and Obesity-Related High Risk Factors 2001. JAMA.;289(1).

Muthukumaran J.S.S, Venkatesan,R.S., Ramachandran,V., Muruganathan, U. (2013). Syringic acid, a novel natural phenolic acid, normalizes hyperglycemia with special reference to glycoprotein components in experimental diabetic rats. Journal of Acute Disease.:304-9.

Natah S.S HKR, Tuominen J.A, Koivisto V.A (1997). Metabolic response to lactitol and xylitol in healthy men. Am J Clin Nutr. ;65:947 - 50.

Petiti DB CR, Dudl J. (2001). Randomized trial of fructosamine home monitoring in patients with diabetes. American College of Physicians-Am Soc of Int Med ;4:1822.Shaw J.E. RAS, Zimmet P.Z. (2010). Global estimates of the prevalence of diabetes for 2010 and 2030. diabetes 
research and clinical practice 8 (7):414.

Perkeni. (2011). Konsensus Pengelolaan Diabetes Melitus Tipe 2 di Indonesia. Semarang.

Rahayu L, Zakir, L., dan Keban, S.A (2013). The Effect Of Rambutan Seed (Nephelium lappaceum L.) Infusion On Blood Glucose And Pancreas Histologi Of Mice Induced With Alloxan. Jurnal Ilmu Kefarmasian Indonesia. 11(1):28-35.

Sluijs I.Y.T, vander D.L.A, Spijkerman,A.M., Hu,F.B., Grobbee,D.E., Beulens JW. (2010). Carbohydrate quantity and quality and risk of type 2 diabetes in the
European Prospective Investigation into Cancer and Nutrition-Netherlands (EPIC-NL) study. Am J Clin Nutr ;92(905).

Yusra A. (2011). Hubungan Antara Dukungan Keluarga Dengan Kualitas Hidup Pasien Diabetes Militus Tipe 2 Di Poliklinik Penyakit Dalam Rumah Sakit Umum Pusat Fatmawati. Jakarta: Universitas Indonesia.

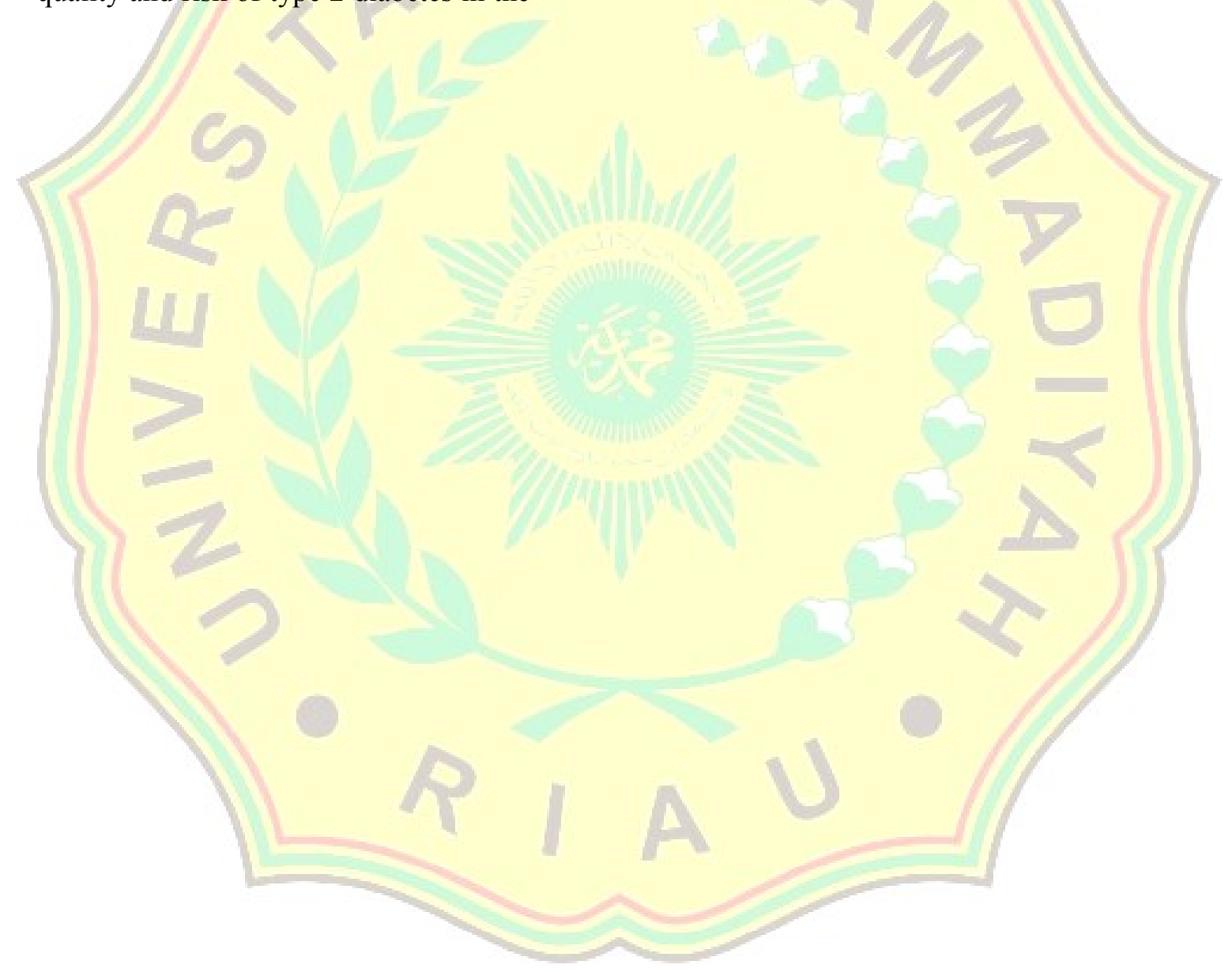

